\title{
The Influence of Promotion and Knowledge for the Completeness of Basic Immunization in Infants
}

\author{
${ }^{1}$ Marniati, ${ }^{2}$ Susy Sriwahyuni, ${ }^{3}$ Nur Nadiah \\ ${ }^{1}$ Faculty of Public Health, Universitas Teuku Umar, Aceh, Indonesia \\ Coresponding author: Marniati, e-mail: marniati@utu.ac.id \\ Co-author : SS: susysriwahyuni@utu.ac.id, NN: nurnadiahbteismail@gmail.com
}

Submitted: 16/09/2020 Revised: 02/10/2020 Accepted: 19/10/2020 Published online: 21/10/2020

doi: https://doi.org/10.35308/j-kesmas.v7i2.2727 How to cite this article: Marniati, M., Sriwahyuni, S., \& Nadiah, N. (2020).

The Influence of Promotion and Knowledge for the Completeness of Basic Immunization in Infants. J-Kesmas: Jurnal Fakultas Kesehatan Masyarakat (The Indonesian Journal of Public Health), 7(2), 105-110.

\begin{abstract}
Background departs of research from immunization coverage problems The background of the study departs from the problem of immunization coverage which is still very low, namely the percentage of immunization coverage in Tangkeh Health Center in 2018 Hb0 15.7\%, BCG 36.3\%, Polio 1 63.7\%, DPT 1 50\%, DPT 2 40.2 \%, Polio 3 38.2\%, DPT 3 22.5\%, Polio $432.4 \%$, Measles $25.5 \%$ of the standard service of at least $99 \%$. This study aims to look at the effect of promotion and knowledge for completeness of basic infant immunization in the working area of Tangkeh Health Center in West Aceh District. Method of reseach wasquantitative method with cast control design. Population amounted to 74, Samples were taken accidentally sampling which is 30 baby mothers. The software used to analyze was SPSS 22 , the bivariate analysis with T-test independent. The results of bivariate analysis was promotion $(\mathrm{P}$ value $0.003<\alpha ; 0.05)$ and knowledge $(\mathrm{P}$ value $0.012<\alpha$; 0.05), which means was the promotion and knowledge have an influence on completeness of basic immunization in infants with a poin of promotion higher average posttest (9.77) better than pretest (5.50) and with poin of knowledge higher average posttest (8.75) better than pretest (6.35). The conclusion of the study was the promotion and knowledge influences the completeness of basic immunization in infants.
\end{abstract}

Keywords: Promotion, Knowledge, Basic Imunitation, Infants.

\section{Introduction}

Immunization is granting immunity to a disease by inserting something into the body so that the body's resistance to disease is endemic or harmful to someone. Immunization comes from the word immune, which means immune or resistant. Immunization is an attempt to provide immunity to infants and children by introducing vaccines into the body so that the body makes antibodies to prevent certain diseases. The Immunization Program is an effort to prevent certain diseases, as for those that can be prevented through immunizations such as including tuber culosis and hepatitis B, and others. every baby (0-11 months) should get immunizations .(Kemenkes RI, 2017; Kementerian Kesehatan Republik Indonesia, 2019; Kementerian kesehatan RI, 2014; Marimbi, 2014; Maryunani, 2017)

In Indonesia, Basic Basic Immunization has not reached the expected target, it can be seen that in 2016 only $84 \%$ while the target to be achieved is $92 \%$. In 2017 the achievement of immunization was $85.41 \%$ that had not reached the target of $93 \%$. Then in 2018 it will decrease from the previous two years $81.99 \%$ of the target that must be met is
94\%.(Kementrian Kesehatan Republik Indonesia (KemenKes RI), 2019; World Health Organitation (WHO), 2019).Aceh Province in 2016 the achievement of complete basic immunization was $74.1 \%, 2017$ decreased to $54.84 \%$ and in 2018 it was even lower at $39.40 \%$. Data obtained from the Tangkeh Health Center in 2017 covered Immunization $36.05 \%$, in $2018 \mathrm{Hb} 0$ achieved $15.7 \%$, BCG 36.3\%, Polio $163.7 \%$, DPT $150 \%$, DPT 2 40.2\%, Polio $338.2 \%$, DPT $322.5 \%$, Polio $432.4 \%$, Measles 25.5\%, but still have not reached the expected target of 90\%.(Dinas Kesehatan Aceh Barat, 2019; Kementerian Kesehatan Republik Indonesia (Kemenkes RI), 2019; Tangkeh, 2019)

Based on a survey conducted by health workers, so far there have been various ways to improve immunization achievements, from counseling at posyandu, to residents' homes to socializing free immunization and the function of immunization itself, according to officials so far even though mothers come to posyandu but they do not understand the importance of immunization in infants due to low knowledge. The results of interviews with baby mothers, some mothers have never brought their babies at all to be immunized because he did not 
understand the importance of immunization, they also lack information or promotion that is accurate about immunization. however there are some baby mothers who have received immunization counseling at the nearest puskesmas or posyandu, the reason they do not immunize their children, the mothers claim to not understand what immunization is, and the lack of information they receive.n addition, for fear of having a baby with a fever, another reason is because their baby wants to be immunized and not immunized the same as it is time to get sick it will get sick too, then another reason is that they have passed down from not immunizing their children so they are used to not immunizing their babies. . information and knowledge about immunization (Noh, J. W., et all., 2018)

Impact If the child is not immunized at all, the child will be at risk of many diseases that can be prevented by immunization such as hepatitis and others, he severity of the disease can cause death in children. The immune system in children who are not immunized is not as strong as children who are immunized, the body does not recognize the disease virus that enters the body so it cannot fight it, this makes the child vulnerable to disease. If this unimmunized child suffers from illness, he can also transmit it to those around him so that it can also endanger others. (Yousief, S. W., M., et, all, 2020).

The problem in this research is the lack of promotion of the importance of immunization for infants so that the mother of the baby does not understand the consequences of not immunizing the baby. With this problem, it has an impact on immunization outcomes at the Tangkeh health center.

\section{Materials and Methods}

This type of research is quantitative with a case control method that is an observational study conducted by comparing between case groups and control groups based on their exposure status.(Aziz, 2017; Nursalam, 2017; Sugiyono, 2016). This study aims to determine the effect of counseling and knowledge on the completeness of basic immunization in infants in the work area of Tangkeh Health Center in West Aceh Regency.

The population is the whole object of the study or the object under study. (Sopiyudin Dahlan, 2016)The population in this study was all 74 infant mothers in the TangkehPuskesmas working area, with sampling taken by accidental sampling, which was done by taking respondents who happened to be available during the research, in July, there were 30 baby mother samples. The research data were collected using a questionnaire that had been designed, the research data were processed using the T-Independent test.(Ghozali, 2016; Rahman, 2015).

\section{Results and Discussion}

This research was conducted at Tangkeh Health Center, West Aceh Regency on 1 - 5 July 2018. Tangkeh Health Center is located at East Woyla District, West Aceh Regency. The coverage of TangkehPuskesmas's work area consists of 26 villages. WoylaTimurSubdistrict is located approximately $55.5 \mathrm{~km}$ from the center of Meulaboh. The closest village is PayaMeugendrang Village and the farthest is Seuradep Village, with a hilly area and generally a village located on a mountainside and in a forest area, all villages in East Woyla District are included in the criteria of very remote with the central government there in the Tangkeh village, which is a flat bouquet.

The number of residents in the Keja Area Tangkeh Health Center, East Woyla District, West Aceh Regency was 4,324 with a classification of 2,176 men and 2,148 women, Then 63 health workers consisted of 21 civil servants, 15 PTT midwives, 1 contracted person and 26 devoted people..

\section{Analysis of $T$ Test on the Effect of Counseling on the Completeness of Basic Immunization in Infants in the Work Area of Tangkeh Health Center in West Aceh Regency}

Table 1. Effects of Counseling on Completeness of Basic Immunization in Infants.

\begin{tabular}{ccccc}
\hline Variable & N & Mean & $\begin{array}{c}\text { Deviation } \\
\text { Standard }\end{array}$ & P Value \\
\hline Case & 30 & 5.50 & 1,302 & 0,003 \\
Control & 30 & 9,77 & 0,352 & 0,003 \\
\hline
\end{tabular}

Based on Table 1. from the results of the T test the effect of counseling on the completeness of daasar immunization in the work area of Tangkeh Health Center in West Aceh Regency as many as 30 samples is known that can be obtained a value ( $\mathrm{P}$ value: $0.003<\alpha: 0.05$ ) so that Ho is rejected then it can be concluded that there is the effect of counseling on basic immunization knowledge in mothers, with 
an average Post Test score (9.77) higher than that of mothers before pretesting (5.50).

Health counseling is an educational activity carried out by spreading the message, instilling confidence, so that the community is not only aware, know and understand, but also wants and can do a suggestion that has to do with health. Health education is a combination of various activities and opportunities based on the principles of learning to achieve a situation, where individuals, families, groups or communities as a whole want to live healthy, know how and do what can be done, individually or in groups and ask help. (Vela, L. R., et all, 2020).

According to the researchers' assumptions from the results of this study, mothers who received counseling and underwent a post test had an average higher value than mothers who did not receive counseling and prior to pretesting. It is clear that from the observations and research of researchers that counseling is very important to be obtained by mothers who have children especially about immunization where mothers who get counseling about immunization will be more understanding about immunization, types of immunization, immunization benefits and side effects if child is not immunized.

In line with research conducted by Septiarinientitled the effect of counseling on immunization, the result of analysis was it appears that for the counseling variable regarding on the completeness basic immunization obtained $\mathrm{p}$ value < $\alpha: 0.05$ means that there is an influence of counseling on knowledge about basic immunization. Furthermore, it can be concluded that counseling has an influence on increasing respondents' knowledge regarding basic immunization. (Breakwell, L., et, all, 2020). This is also in line with research conducted by Arumsari which states that communication by health workers has an influence on the status of basic immunization in infants.(Arumsari, 2015) The Triana Research states that health information that is carried out through promotion health given to mothers can affect the completeness of basic immunization in infants.(Triana, 2017).

\section{Analysis of $T$ Test on the Influence of Knowledge on the Completeness of Basic Immunization in Infants in the Work Area of Tangkeh Health Center in West Aceh Regency}

Table 2. Effects of Knowledge on Completeness of Basic Immunization in Infants.

\begin{tabular}{ccccc}
\hline Variable & N & Mean & $\begin{array}{c}\text { Deviation } \\
\text { Standard }\end{array}$ & P Value \\
\hline Case & 30 & 6.35 & 1,304 & 0,353 \\
Control & 30 & 8,75 & 0,353 & 0,353 \\
\hline
\end{tabular}

Based on Table 2. from the results of the T test the effect of knowledge on the completeness of daasar immunization in the work area of Tangkeh Health Center in West Aceh Regency as many as 30 samples known that can be obtained a value ( $\mathrm{P}$ value: $0.012<\alpha: 0.05)$ so that Ho is rejected then it can be concluded that there is the effect of counseling on basic immunization knowledge on mothers, with an average Post Test score (6.35) higher than mothers before pretesting $(8,75)$.

Broadly speaking according to the domain of the level of knowledge (cognitive) has six levels, including: knowing, understanding, using, describing, inferring and evaluating. The main characteristic in the level of knowledge is the memory of something he knows well through experience, learning, information received from others. Knowledge is the result and this happens after people have sensed a certain object.(goleman, daniel; boyatzis, Richard; Mckee, 2019; Induniasih; Ratna, 2017; Kholid, 2018)
According to the assumptions of researchers from the results of this study that the knowledge of mothers who do the Post Test on average a higher value than the knowledge of mothers who have not done a pretest. It is clearly seen that after conducting a post-test, the mothers have increased their knowledge, knowledge and knowledge, especially regarding immunization, knowledge is very useful for mothers who have children as insight and knowledge in monitoring children's growth and development, regarding the health status of children to their efforts. One of the efforts that can be done by mothers to prevent children from diseases is by immunization.

Based on research conducted by Yunitasari on the Influence of Mother's Knowledge of Basic Immunization and Completeness of Basic Infant Immunization, the results of the study show that there is a significant relationship ( $p<0.027$ ) between maternal knowledge and the completeness of infant basic immunization. Knowledge about immunization includes knowing the meaning of immunization, diseases that can be prevented through immunization, 
immunization benefits, place of immunization service, timing of immunization, type of immunization and number of immunization. (Yunitasari, Nastiti, Hasan, Yusuf, \& Nugroho, 2018)Research Juwita, Hermayanti, Momomuat, also states that there is an influence of maternal knowledge on the completeness of basic immunization in infants.( Hermayanti, Yulidasari, \& Pujianti, 2016; Juwita, 2018; Momomuat \& Kundre, 2014)

Through sufficient knowledge, it is expected to influence a mother's actions in giving complete immunizations to her child. The results of this study are also in line with the theory about stating that there is a tendency of someone who is highly knowledgeable will tend to have good behavior in the health sector in this case to immunize their children. (goleman, daniel; boyatzis, Richard; Mckee, 2019; Kholid, 2018)

Similar results were also obtained in the study of Arumsari, 2015 which stated that mother's knowledge influences the basic immunization status of toddlers with a value (P value <0.05). Dewi, 2014 also stated that there was influence of maternal knowledge by giving immunizations ( $\mathrm{P}$ value $<0.05$ ).In line with Triana's study, 2015 that maternal knowledge is related to complete basic immunization.(Arumsari, 2015; Putri Dewi \& Darwin, 2014; Triana, 2017)

\section{Conclusion}

Based on the results of research that has been done that the presentation of the number of counseling followed and the value of a higher level of knowledge of mothers affected the basic immunization skills in infants.

\section{Acknowledgement}

This research was carried out well because of help from other parties.

\section{Author Contribution and Competing Interest}

All of the authors contributed in collecting and analyzing the data, including preparing the manuscript. The author assures thet there is no conflict of interest in the activities and preparation of this report.

\section{Publisher's Note}

J-Kesmas: Jurnal Fakultas Kesehatan Masyarakat (Indonesia Journal of Public Health) remains neutral with regard to jurisdictional claims in published institutional affiliation.

\section{References}

Abdullah, I.R. (2014) Risk factors of traffic accident incidents in the bentor in the limboto district police of gorontalo regency 2007-2009. Jurnal Masyarakat Epidemiologi, 2(2): 108-112

Afriani, T., Andrajati, R., \& Supardi, S. (2014). Faktor-Faktor Yang Berhubungan Dengan Kelengkapan Imunisasi Dasar Pada Anak Dan Pengelolaan Vaksin Di Puskesmas Dan Posyandu Kecamatan X Kota Depok. Buletin Penelitian Sistem Kesehatan, 17(2), 135-142.

Arumsari, D. R. (2015). Faktor-Faktor yang Berhubungan dengan Status Imunisasi Dasar Pada Bayi. Jurnal Pendidikan Kesehatan, 4(1), 9-15.

Atika Putri Dew. (2014). Hubungan Tingkat Pengetahuan Ibu Dengan Pemberian Imunisasi Dasar Lengkap Pada Bayi Di Kelurahan Parupuk Tabing Wilayah Kerja Puskesmas Lubuk Buaya Kota Padang Tahun 2013. Jurnal Kesehatan Andalas, 3(2): 114-118.

Breakwell, L., Anga, J., Cooley, G., Ropiti, L., Gwyn, S., Wannemuehler, K., ... Tohme, R. A. (2020). Seroprevalence of chronic hepatitis $B$ virus infection and immunity to measles, rubella, tetanus and diphtheria among schoolchildren aged 6-7 years old in the Solomon Islands, 2016. Vaccine. 38(30): 46794686.

Buffarini, R., Barros, F. C., \& Silveira, M. F. (2020). Vaccine coverage within the first year of life and associated factors with incomplete immunization in a Brazilian birth cohort. Archives of Public Health, 78(1): 2-8

Darmayanti, D., \& Lipoeto, N. I. (2020). Gambaran Pemenuhan Hak Anak serta Faktor-Faktor yang Mendukung pada Klaster Kesehatan Dasar dan Kesejahteraan dalam Implementasi Kebijakan Kota Layak Anak Kota Bukittinggi tahun 2019. Jurnal Kesehatan Andalas, 8(4): 44-55

de Almeida, R., Nakamura, C. N., de Lima Fontes, M., Deffune, E., Felisbino, S. L., Kaneno, R., ... Moroz, A. (2018, January 2). Enhanced 
immunization techniques to obtain highly specific monoclonal antibodies. MAbs. Taylor and Francis Inc. 10(1): 46-54

Dinas Kesehatan Aceh Barat. (2019). Data Cakupan Imunisasi Dasar Di Aceh Barat. Meulaboh

Dwiastuti P. (2012). Faktor-Faktor Yang Berhubungan Dengan Pemberian Imunisasi BCG Di Wilayah Kerja Puskesmas UPT Cimanggis Kota Depak Tahun 2012. Jurnal Ilmiah Kesehatan, 5(1): 36-41.

Hidayah, N., Sihotang, H. M., \& Lestari, W. (2018). Faktor Yang Berhubungan Dengan Pemberian Imunisasi Dasar Lengkap Pada Bayi Tahun 2017. Jurnal Endurance, 3(1): 153.

Juwita, R. (2018). Faktor-Faktor Yang Mempengaruhi Status Imunisasi Dasar Pada Bayi Di Desa Sungai Air Putih Kecamatan Sungai Lala Kabupaten Indragiri Hulu. $A l$ Tamimi Kesmas, 7(2): 11-21.

Kalsum, U., Halim, R., \& M.Ridwan. (2020). Peran Dukun Dan Tuo Tengganai Sebagai Mediator Pesan Imunisasi Melalui Tradisi "Ngerawi" Di Kecamatan Batang Asai, Sarolangun Jambi. Jurnal Khazanah Intelektual, 2(3): 268-289

Kementerian Kesehatan Republik Indonesia (Kemenkes RI). (2019). Data Cakupan Imunisasi di Aceh. Jakarta.

Kementerian kesehatan RI. (2014). Buku Ajar Imunisasi. In Hari Aids Sedunia 2014. https://doi.org/351.077 Ind r

Kementrian Kesehatan Republik Indonesia (KemenKes RI). (2019). Data Cakupan Imunisasi di Indonesia. jakarta.

Kementerian Kesehatan Republik Indonesia. (2019). Buku Ajar Imunisasi Kementerian Kesehatan Republik Indonesia. In Kementerian Kesehatan RI.

Kibreab, F., Lewycka, S., \& Tewelde, A. (2020). Impact of mother's education on full immunization of children aged 12-23 months in Eritrea: population and health survey 2010 data analysis. BMC Public Health, 20(1): 267.

Laeli Syukuriyah, N., Martomijoyo, R., \& Rahmawati, A. (2019). Faktor-Faktor Yang Berhubungan Dengan Pemberian Imunisasi Dasar Pada Balita Di Desa Purwajaya Kecamatan Karangampel Kabupaten Indramayu Tahun 2019. Afiasi: Jurnal Kesehatan Masyarakat, 4(2): 70-76.
Marimbi, H. (2014). Tumbuh Kembang, Status Gizi, Dan Imunisasi Dasar Pada Balita. Yogyakarta: Nuha Medika

Mardianti, M., \& Farida, Y. (2020). Faktor - Faktor Yang Berhubungan Dengan Status Imunisasi Dasar Pada Bayi Di Desa Rengasdengklok Selatan Kabupaten Karawang. Jurnal Kebidanan Indonesia: Journal Of Indonesia Midwifery, 11(1): 17.

Ningsih, F., Kasanova, E., \& Devitasari, I. (2016). Hubungan Peran Orang Tua Dan Petugas Kesehatan Dengan Kelengkapan Imunisasi Pada Keluarga Yang Memiliki Bayi Usia 0-12 Bulan Di Wilayah Kerja Pusekesmas Pahandut Kota Palangka Raya. Jurnal SURYA, 8(2): 5863.

Noh, J. W., Kim, Y. M., Akram, N., Yoo, K. B., Park, J., Cheon, J., ... Stekelenburg, J. (2018, October 1). Factors affecting complete and timely childhood immunization coverage in Sindh, Pakistan; A secondary analysis of crosssectional survey data. PLoS ONE. Public Library of Science, 13(10): 1-15.

Nozaki, I., Hachiya, M., \& Kitamura, T. (2019). Factors influencing basic vaccination coverage in Myanmar: Secondary analysis of 2015 Myanmar demographic and health survey data. BMC Public Health, 19(1): 242.

Pradita Diah Permatasari, Muhammad Fadil, Masrul Syafri. (2020). Description Of ST Segments Elevation Of Myocardial Infarction On Patients Undergoing Primary Percutaneous Coronary Intervention In Dr. M. Djamil Hospital Padang, Jurnal J Kesmas, 7(1): 1-5.

Pramodya, R. D., Susanti, A. I., \& Nirmala, S. A. (2016). Pengaruh Penyuluhan Mengenai Imunisasi Terhadap Pengetahuan Dan Sikap Ibu Di Desa Sukarapih Kec. Sukasari. Jurnal Sistem Kesehatan, 1(2): 48-54.

Robin Dompas. (2014). Gambaran Pemberian Imunisasi Dasar Pada Bayi Usia 0-12 Bulan. Jurnal Ilmiah Bidan (JIDAN), 2(2): 71-76.

Simanjuntak, S. M., \& Nurnisa, I. N. (2019). Peningkatan Pengetahuan Dan Sikap Ibu Tentang Imunisasi Dengan Pendekatan Promosi Kesehatan Tentang Imuniasi Dasar. Media Karya Kesehatan, 2(1): 38-52.

Sari, W., \& Nadjib, M. (2019). Determinan Cakupan Imunisasi Dasar Lengkap Pada Penerima Program Keluarga Harapan. Jurnal Ekonomi Kesehatan Indonesia, 4(1): 1-9. 
Sari, D. N. I., Basuki, S. W., \& Triastuti, N. J. (2017). Hubungan Pengetahuan Ibu Tentang Imunisasi Dasar Dengan Kelengkapan Imunisasi Dasar Bayi Di Wilayah Kerja Puskesmas Bendo Kabupaten Magetan. Biomedika, 8(2): 6-12.

Safitri, F., Mufdalina, M., \& Andika, F. (2017). Analisis Faktor-Faktor Yang Berhubungan Dengan Kelengkapan Imunisasi Dasar Pada Balita Di Desa Ujung Bawang Aceh Singkil. Journal of Healthcare Technology And Medicine, 3(2): 166.

Setiyowati, W., \& Nurhaeni, N. (2019). Does Complete Basic Immunization Correlate with Pneumonia Incidents in Children under Five Years in Depok, Indonesia?. Comprehensive Child and Adolescent Nursing, 42(sup1): 291299.

Tanjung, I. C. D., Rohmawati, L., \& Sofyani, S. (2017). Cakupan Imunisasi Dasar Lengkap Dan Faktor Yang Memengaruhi. Sari Pediatri, 19(2): 86.

Tangkeh, P. (2019). Data Cakupan Imunisasi Dasar Di Puskesmas Tangkeh. Meulaboh.

Teuku Alamsyah, Dewi Marianthi. (2020). Correlation Between Incidence Of Diarrhea In Toddlers And Housewife's Clean And Healthy Lifestyle. Jurnal J Kesmas, 7(1): 57-62.

Thaib, T., Darussalam, D., Yusuf, S., \& Andid, R. (2016). Cakupan Imunisasi Dasar Anak Usia 1-5 Tahun Dan Beberapa Faktor Yang Berhubungan Di Poliklinik Anak Rumah Sakit
Ibu Dan Anak (Rsia) Banda Aceh. Sari Pediatri, 14(5): 283.

Vela, L. R., \& Sjaaf, A. C. (2020). Policy Implementation In Achieving Basic Complete Immunization And Universal Child Immunization Indicators In Kapuas District In 2018. Journal Of Indonesian Health Policy And Administration, 5(1): 14-19.

Vivi Triana. (2016). Faktor Yang Berhubungan Dengan Pemberian Imunisasi Dasar Lengkap Pada Bayi Tahun 2015, Jurnal Kesehatan Masyarakat Andalas, 10(2): 123-135.

Wahyuni Hafid, Santi Martini, Shrimarti R Devy. (2016). Faktor Determinan Status Imunisasi Dasar Lengkap Pada Bayi Di Puskesmas Konang Dan Geger. Jurnal Wiyata, 3(1): 3845.

World Health Organitation (WHO). (2019). Data Cakupan Imunisasi Dasar Di Dunia

Yousief, S. W., Bahey-El-Din, M., \& Zaghloul, T. I. (2020). Immunization with the basic membrane protein (BMP) family ABC transporter elicits protection against Enterococcus faecium in a murine infection model. Microbes and Infection, 22(3): 127136

Yunitasari, E., Nastiti, A. A., Hasan, W. D., Yusuf, A., \& Nugroho, H. S. W. (2018). Factors Associated To Infant Vaccination In Madurese, Indonesia. Indian Journal Of Public Health Research And Development, 9(10): 364-368. 